\title{
Sustainable Glass Foams Produced from Glass Bottles and Tobacco Residue
}

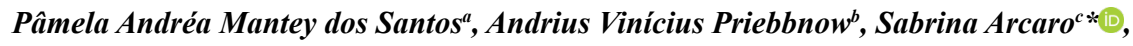
Rafael Martins da Silva ${ }^{a}$, Diosnel Antonio Rodriguez, Lopez ${ }^{a, b}$, Adriane De Assis Lawisch Rodriguez ${ }^{a, b}$

\author{
aPrograma de Pós-Graduação em Tecnologia Ambiental, Universidade de Santa Cruz do Sul, Av. \\ Independência, 2293, 96815-900, Santa Cruz do Sul, RS, Brazil \\ ${ }^{b}$ Departamento de Engenharia, Arquitetura e Ciências Agrárias, Universidade de Santa Cruz do Sul, Av. \\ Independência 2293, 96815-900, Santa Cruz do Sul, RS, Brazil \\ cPrograma de Pós Graduação em Engenharia de Minas, Metalúrgica e Materiais, Departamento de \\ Materiais, Laboratório de Materiais Cerâmicos, Escola de Engenharia, Universidade Federal do Rio \\ Grande do Sul, Av. Osvaldo Aranha, 99, 90035-190, Porto Alegre, RS, Brasil
}

Received: June 28, 2018; Revised: September 22, 2018; Accepted: November 02, 2018

\begin{abstract}
In this work, discarded soda-lime-silica glass bottles and tobacco residue (after oil extraction to produce biodiesel) were prepared in different formulations to obtain glass foams. The formulated compositions were homogenized and uniaxially compacted at $40 \mathrm{MPa}$ then fired at $850{ }^{\circ} \mathrm{C}$ and $900{ }^{\circ} \mathrm{C}$ for $60 \mathrm{~min}$ to investigate the effects of tobacco residue and temperature in thermal and mechanical properties of the glass foams. The results show that glass foams obtained are promising materials for applications where thermal insulation and mechanical strength are desired, with values of $0.087 \mathrm{~W} . \mathrm{m}^{-1} \mathrm{~K}^{-1}$ and $2.1 \mathrm{MPa}$, respectively for $45 \%$ of the tobacco residue that was added to the glass foam and fired at $850{ }^{\circ} \mathrm{C}$. These characteristics occur through a suitable combination of thermal conductivity and compressive strength, showing advantageous properties for applications in sustainable constructions and industrial energy efficiency.
\end{abstract}

Keywords: Glass foams, agro-industrial waste, tobacco residue.

\section{Introduction}

In Brazil, around 980 thousand tons of glass bottles are produced annually, and only approximately $50 \%$ of this amount is recycled ${ }^{1}$. Glass is a material of high durability and is inert, which gives it a high reuse rate. The production of glass foams represents an excellent alternative for the reuse of glass waste. This waste is applied as glass foams mainly for thermal insulation due of its low density, high porosity $(>60 \%),{ }^{2}$ low thermal conductivity $\left(0.04-0.08 \mathrm{~W} \cdot \mathrm{m}^{-1} \cdot \mathrm{K}^{-1}\right)^{3}$, dimensional stability, and also because it is non-toxic, nonflammable, chemically inert and has compressive strength values ranging from $0.4-6 \mathrm{MPa}^{3}$. In addition, glass waste has higher operating temperatures than conventional insulation materials (polymer foams). Other possible applications are their use as filters, supports for catalysts and lightweight structural materials ${ }^{4-5}$. Thermal insulators are an essential contribution to saving energy in buildings, such as in the control of the loss and gain of heat through walls. This contribution can be an important reason for increasing the use of glass waste. In this way, thermal insulators present a relevant role as a destination for this waste from an economic and environmental point of view. This is due to the fact that glass used for its manufacture is not always returnable or reused in the manufacture of new packaging. In addition, the development of studies aimed at the aggregation of agroindustrial residues as a pore-forming agent in the vitreous matrix can become an alternative capable of reducing the use of raw materials and lengthening the life cycles of elements in the anthroposphere. This reduces the need for extracting natural resources from the environment and reduces the final costs for the industrial sectors ${ }^{6-7}$.

Tobacco is valued mainly for its leaves which are used in the production of cigarettes and other tobacco products. Recently, alternative uses of tobacco have been proposed. One of which is energetic tobacco. This is a variety of Solaris tobacco which was developed in Italy. It is a type of genetically modified tobacco that has very low levels of nicotine and is useful as an alternative energy resource. Various tests have been used on energetic tobacco planted in the Vale do Rio Pardo region, Rio Grande do Sul, in Brazil to assess the quality and possibility of planting it in the soil where previously traditional tobacco was cultivated ${ }^{8-9}$. The energetic tobacco seed, which is used for biodiesel extraction, generates approximately $40 \%$ oil ${ }^{10}$ and appears to be a sustainable option for the production of biofuels ${ }^{8,11-12}$. The process of extracting the oil from the tobacco seed produces tobacco residue as a byproduct (approximately $60 \%$ ), which is a residue that does not yet have an adequate disposal destination ${ }^{8}$. 
In this context, the objective of this work is to develop sustainable glass foams using tobacco residue as organic pore forming agents and glass powder obtained from glass bottles as a matrix. It is important to highlight the study's concern for a sustainable destination of waste in the environmental area, since this will provide added value to two significant types of industrial waste.

\section{Materials and Methods}

In this study, green glass bottles (the soda-lime type) and tobacco residue $(\mathrm{T})$, (originating from oil extraction for biodiesel production, ) were used as an alternative vitreous matrix and pore forming agents.

Samples of dried tobacco residue were milled ( $5 \mathrm{~min}$ in a in a ball mill (Servitech, CT-242) and subsequently sieved to ensure that the particle size was below $90 \mu \mathrm{m}$ (170 Mesh).

The powder samples obtained were characterized by proximate chemical analysis according to procedures described in ASTM E1871-82 (2006) ${ }^{13}$ for moisture, ASTM E872-82 (2006) ${ }^{14}$ for volatile materials, ASTM E1755-01 (2007) ${ }^{15}$ for ash, and ASTM E1756-08 (2008) ${ }^{16}$ for total solids and fixed carbon.

The glass bottles were washed and dried at $110^{\circ} \mathrm{C}$ for $2 \mathrm{~h}$. In a subsequent step, they were fragmented with a hammer and then milled for $120 \mathrm{~min}$ in a ball mill (Servitech, CT-242) until reaching an 80 mesh (177 microns) particle diameter. The glass powder was labeled GP. The chemical composition of glass powder was obtained by X-ray fluorescence (Philips, model PW 2400). The sample was prepared in pressed pellets.

To obtain the glass foams, different formulations were prepared (100\% GP, 95\% GP - 5\% T w/w, 85\% GP - 15\% T w/w, 70\% GP - 30\% T w/w and 55\% GP - 45\% T w/w). The formulated compositions were homogenized and humidified with an additional $10 \%(\mathrm{w} / \mathrm{w})$ of water for better conformation of the samples. The powders were compacted uniaxially at a pressure of $40 \mathrm{MPa}$ in a hydraulic press (Nowak, PH30) to obtain glass foams with a size of $(60 \times 20 \times 5) \mathrm{mm}$. The samples were fired at $850^{\circ} \mathrm{C}$ and $900{ }^{\circ} \mathrm{C}$ at a heating rate of $10^{\circ} \mathrm{C} . \mathrm{min}^{-1}$ for $60 \mathrm{~min}$. True density $\left(\rho_{t}\right)$ of glass foams (crushed and milled cell walls) were determined using a helium pycnometer (AccuPyc 1340, Micromeritics). Apparent densities $\left(\rho_{a}\right)$ of glass foams were determined by relating their geometric dimensions (obtained using a caliper, model Mitotoyo) and their masses (obtained with analytical balance FA-2104N, Bioprecisa). Porosity $(\varepsilon)$ of glass foams was calculated from geometric measurements and true density was determined according to Equation 1:

$$
\varepsilon(\%)=\left[1-\left(\frac{\rho_{a}}{\rho_{r}}\right)\right] * 100
$$

Pore microstructure could be visualized from images of fracture surfaces of fired foams obtained in an optical microscope (Olympus, 3Z61). Mean pore size for the glass foams were determined by quantifications corresponding to the specified pore diameter ranges. This was based on the linear intercept method (ASTM E112-12 ${ }^{17}$ ) where the ratio between the average length string $(\mathrm{t})$ and average sphere diameter (D) is determined by Equation 2 to better represent the measurement of a 3D unit (pore) by a 2D image (ASTM D3576-98R $15^{18}$ ).

$$
D=1.623 t
$$

In this case, five images of the fractured surfaces from each foam were used, and 200 measurements of each image, on average, were made with the aid of (Image $(\circledR)$ ) software.

The thermal conductivity of glass foams was determined in a TCi Thermal Conductivity Analyzer, C-THERM TECHNOLOGIES ( 0 to $100 \mathrm{~W} \cdot \mathrm{m}^{-1} \cdot \mathrm{K}^{-1}$ measurement range).

The compressive strength of glass foams was measured with nominal dimensions $(10 \times 10 \times 10) \mathrm{mm}$ in a universal test machine (EMIC, model DL 10000, cross speed 1.0 mm. min $^{-1}$ ) according to ASTM C133 - 97R15 (2015) ${ }^{19}$. Ethylene-vinyl acetate sheets were used on the samples for uniform charge distribution.

\section{Results and Discussions}

Table 1 shows the results of chemical analysis of the glass powder. It is mainly composed of silicon oxide, calcium oxide and sodium oxide. In addition to these oxides, the presence of aluminum oxide and magnesium oxide was also observed. These two oxides are typically found in soda-lime glass as a structural stabilizer which increases chemical durability ${ }^{20}$. When the amount of iron oxide varies between $0.1 \%$ and $0.8 \%$, the clear glass turns green and brown. In this work, the glass bottles used were green, which justifies the iron oxide content. The chemical composition found for glass powders is typical of soda-lime glass ${ }^{20}$.

According to the approximate chemical analysis (Table 2), the T has $73.13 \%$ of volatile solids. This is due to degradation of hemicellulose, cellulose and lignin, which are constituents of the biomass. Volatiles are subdivided into gases, such as light hydrocarbons, carbon monoxide (traces), carbon dioxide and tar. After the degradation, fixed carbon (12.02\%) and ashes (14.84\%) remain. They have a significant amount of carbon that causes the formation of gases in temperatures between 600 and $1000{ }^{\circ} \mathrm{C}$.

By the chemical analysis of the tobacco residue it is possible to verify the main element present is silica, followed by potassium, calcium and magnesium. In addition, residual amounts of titanium, alumina, sodium and iron were observed. These compounds are commonly found in plants. The mass loss of the tobacco residue was $85 \%$, corroborating with the results of approximate analysis, leaving 15\% ash. X-ray diffraction analysis of the ashes of this residue (Figure 1) shows that the crystalline phases present are quartz (JCPDS: 
Table 1. Chemical composition of bottle glass powder and Tobacco residue.

\begin{tabular}{lcc}
\hline $\begin{array}{l}\text { Constitutive } \\
\text { Oxides (wt.\%) }\end{array}$ & $\begin{array}{c}\text { Glass Powder } \\
\text { (wt.\%) }\end{array}$ & $\begin{array}{c}\text { Tobacco residue } \\
\text { (wt.\%) }\end{array}$ \\
\hline $\mathrm{SiO}_{2}$ & 68.30 & 9.12 \\
$\mathrm{Al}_{2} \mathrm{O}_{3}$ & 2.07 & 0.70 \\
$\mathrm{Fe}_{2} \mathrm{O}_{3}$ & 0.41 & 0.26 \\
$\mathrm{CaO}$ & 8.94 & 1.60 \\
$\mathrm{~K}_{2} \mathrm{O}$ & 0.44 & 2.10 \\
$\mathrm{MgO}$ & 1.80 & 1.05 \\
$\mathrm{Na}_{2} \mathrm{O}$ & 17.95 & 0.10 \\
$\mathrm{P}_{2} \mathrm{O}_{5}$ & 0.01 & - \\
$\mathrm{TiO}_{2}$ & 0.06 & 0.08 \\
$\mathrm{~L}_{2} \mathrm{O} . I^{*}$ & - & 85 \\
\hline
\end{tabular}

*Loss-on-ignition

Table 2. Proximate chemical and elemental analysis of tobacco residue samples.

\begin{tabular}{lc}
\hline Parameters & Content (wt.\%) \\
\hline Moisture & 7,89 \\
Volatile solids & 73,13 \\
Fixed carbon & 12,02 \\
Ashes & 14,84 \\
\hline
\end{tabular}

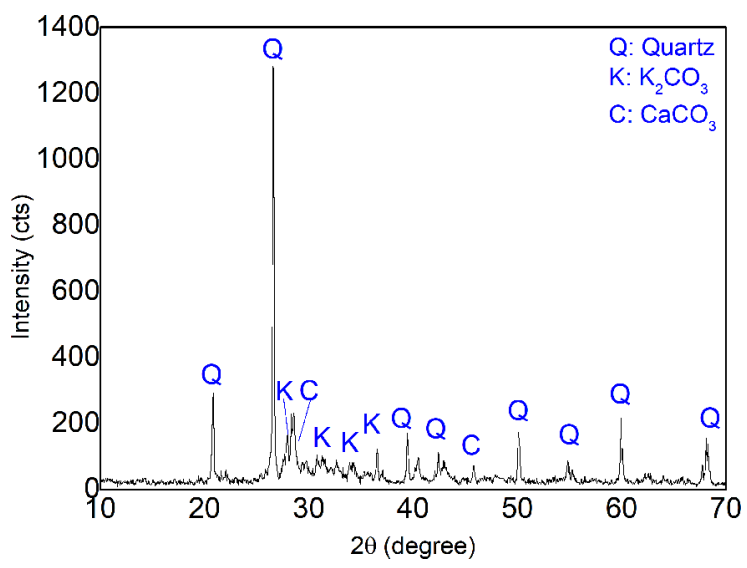

Figure 1. XRD of tobacco residue ash.

01-083-0539), potassium carbonate (JCPDS: 00-049-1093) and calcium carbonate (JCPDS:01-086-2343). The presence of the carbonates, together with the decomposition of fixed carbon with the increase in temperature, favors the formation of pores in the glass foams.

In order to produce glass foam, an adequat firing temperature is critical since it is directly related to the viscosity of the glass and its expansion caused by the release of gas from the decomposition of the pore forming agents. In this case, pores are formed in the vitreous matrix in temperatures up to $650^{\circ} \mathrm{C}$. This is due to the gases released in degradation of hemicellulose, cellulose and lignin. These compounds act as a sacrificial material. These pores form but do not cause matrix expansion. They only occupy the place previously occupied by the tobacco powders. At temperatures above $600{ }^{\circ} \mathrm{C}$, the fixed carbon and ashes are responsible for an expansion of the vitreous matrix. This is due to the release of gases at a temperature which allows for suitable viscosity in the glass. The most convenient viscosity range for the expansion of glass foam production with maximum porosity corresponds to temperatures between $800-1000^{\circ} \mathrm{C}$ using sodalime glass ${ }^{21-22}$. The selected firing temperatures were based on previous work containing agroindustrial residues as pore forming agents ${ }^{6-7,23}$. In these works, the best properties for the obtained glass foams were found at firing temperatures between 850 and $900{ }^{\circ} \mathrm{C}$.

Figure 2 shows the porosity of glass foams produced with different amounts of T fired at temperatures of $850{ }^{\circ} \mathrm{C}$ and $900{ }^{\circ} \mathrm{C}$. The porosity of glass foams produced ranges from $36.7 \%$ to $83.5 \%$. The increase in the amount of tobacco residue causes an increase in porosity mainly at the sintering temperature of $850^{\circ} \mathrm{C}$. However, at $900{ }^{\circ} \mathrm{C}$, the glass foam containing $45 \% \mathrm{~T}$ obtained lower porosity values compared to glass foam containing $30 \% \mathrm{~T}$. These results can also be observed in the optical microscopy images (Figure 3). This fact may be related to the high percentage of the porogenic agent added, which causes excess formation of gases that break the formed walls and consequently allows trapped air to escape. Teixeira, et al. ${ }^{23}$ showed that with higher sintering temperatures there is a decrease in glass viscosity, which is not sufficient to maintain the cell structure, since $950{ }^{\circ} \mathrm{C}$, for example, is very close to the liquidus temperature of the glass $\left(1000^{\circ} \mathrm{C}\right)^{22}$. The glass foams produced have similar porosity values as those found in other works and in commercial products processed under similar conditions ${ }^{6-7,21,23-25}$ demonstrating the efficacy of the residues used to produce glass foams.

Figure 3 shows optical microscopy images of glass foams produced with different contents of tobacco and fired at 850 and $900^{\circ} \mathrm{C}$. It can be inferred that the samples are free of cracks, with uniformly distributed pores and closed porosity. Very similar microstructures are observed for all

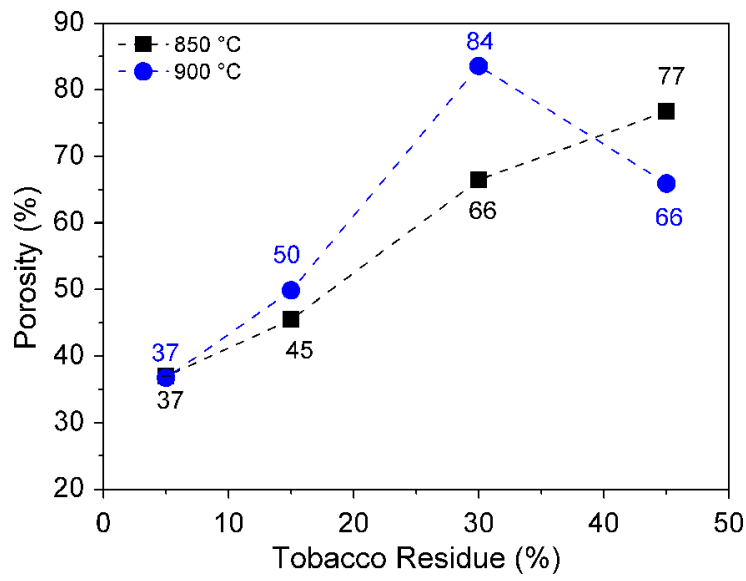

Figure 2. Porosity of glass foams produced containing 5, 15, 30 and $45 \%$ (mass) of $\mathrm{T}$ and fired at 850 and $900{ }^{\circ} \mathrm{C}$. 

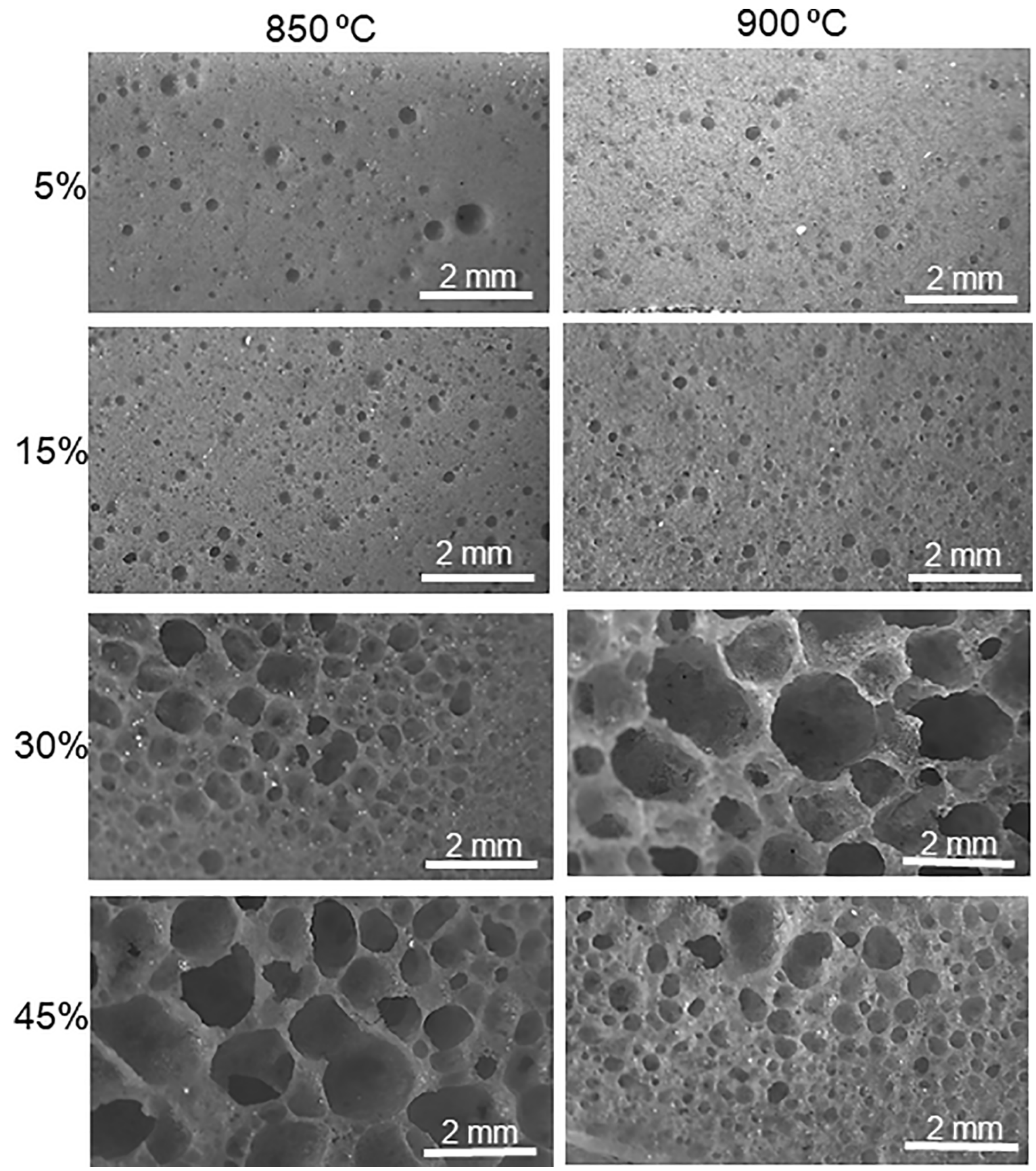

Figure 3. Optical microscopy of glass foams produced containing 5, 15, 30 and $45 \%$ (mass) of T and fired at 850 and $900{ }^{\circ} \mathrm{C}$.

glass foams obtained. In addition, a variation in the porosity (pore quantity and size) is observed with the increase of tobacco residue, seen in Figure 2. At $850^{\circ} \mathrm{C}$, the increase in the addition of tobacco residue results in greater porosity. At $900{ }^{\circ} \mathrm{C}$, similar behavior is observed, until additions of $30 \%$ residue. However, increasing the aggregation of residue, at this temperature, above $30 \%$, a decrease in porosity occurs. This is possibly related to the escape of gases formed in large quantities which causes the breakage of cell walls. Research using glass residues and banana leaves as pore forming agents showed that the addition of an organic agent decreased the apparent density of glass foam with the increase in residue $\left(0.31\right.$ and $\left.1.03 \mathrm{~g} . \mathrm{cm}^{-3}\right)$, consequently increasing its porosity $(58.5 \text { to } 87.5 \%)^{6}$. Glass foams produced from bottle glass residues by the emulsification method using vegetable oil as a porogenic agent presented similar behavior, with porosity varying between 74,85 and $93 \%$ for additions of 50,70 and $90 \%$ oil, respectively ${ }^{26}$.

Table 3 shows the mean pore size of the glass foams produced containing 5, 15, 30 and $45 \%$ (mass) of tobacco 
residue and fired at 850 and $900{ }^{\circ} \mathrm{C}$. Pore sizes in the range of 0.16 to $0.25 \mathrm{~mm}$ can be observed for samples containing 5 and $15 \% \mathrm{~T}$ at the two firing temperatures. The small pores observed are mainly due to the low amount of pore forming agents. Furthermore, at $850^{\circ} \mathrm{C}$ an increase in pore size is observed with increases in the amounts of pore forming agent, up to 1.70 . In this case the pore size can be controlled by the addition of pore forming agent since there is an expansion of the vitreous matrix as a result of more gases being released. On the other hand, at $900{ }^{\circ} \mathrm{C}$ the increase in the amount of tobacco residue from 30 to $45 \%$ decreases the size of the pores, which reinforces the hypothesis that an escape of the formed gases is occurring.

Figure 4 shows XRD diffraction patterns of the amorphous structure of the glass powder (as prepared) and partially crystalline structure of the glass foams containing 45 vol. $\%$ of tobacco residue, fired at 850 and $900^{\circ} \mathrm{C}$. The main reflections were attributed to the crystalline phases of devitrite $\mathrm{Na}_{2} \mathrm{Ca}_{3} \mathrm{Si}_{6} \mathrm{O}_{16}$, (JCPDS-00-023-0671) and $\beta$-quartz (JCPDS-01-089-8949). Crystalline silica which comes from undissolved quartz still exists as the major crystal phase. As for devitrite, it is a typical devitrification product in commercial soda-lime-silica glass.

Crystallisation studies on soda-lime glass show that cristobalite is formed at $665-925^{\circ} \mathrm{C}$ and devitrite at $750-925^{\circ} \mathrm{C}$ in air atmosphere ${ }^{27-28}$ due to the presence of $\mathrm{CaCO}_{3}$ and $\mathrm{K}_{2} \mathrm{CO}_{3}$ which could possibly work as nucleation sites in our

Table 3. Mean pore size of the glass foams produced containing 5 , 15,30 and $45 \%$ (mass) of $\mathrm{T}$ and fired at 850 and $900^{\circ} \mathrm{C}$.

\begin{tabular}{ccc}
\hline $\begin{array}{c}\text { Sample Tobacco } \\
\text { Residue }(\%)\end{array}$ & $850{ }^{\circ} \mathrm{C}$ & $900{ }^{\circ} \mathrm{C}$ \\
\hline 5 & $0.19 \pm 0.05$ & $0.16 \pm 0.05$ \\
15 & $0.25 \pm 0.08$ & $0.24 \pm 0.10$ \\
30 & $0.80 \pm 0.25$ & $2.14 \pm 0.50$ \\
45 & $1.70 \pm 0.50$ & $0.84 \pm 0.20$ \\
\hline
\end{tabular}

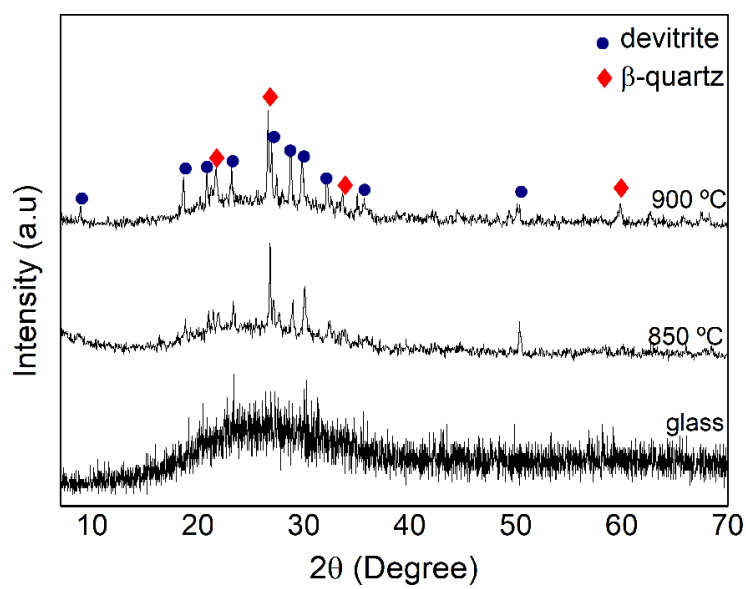

Figure 4. XRD diffraction patterns of the amorphous structure of the glass powder (as prepared) and partially crystalline structure of the glass foams containing $45 \mathrm{vol} \%$ of tobacco residue, fired at 850 and $900^{\circ} \mathrm{C}$. soda-lime-silica glass, inducing crystallisation. However, in this work, only small amounts of these oxides are available which does not favor crystallization of cristobalite.

Previous works containing agroindustrial residues (banana leaf ${ }^{6}$ ) show the formation of cristobalite and devitrite. In these cases, cracks observed in the microstructure of the samples were attributed to cristobalite crystallization. These cracks can be associated with both the heat treatment and the type of plant used (which may contain larger amounts of fluxing agents).

Figure 5 shows thermal conductivity results for glass foams produced after the addition of 5, 15, 30 and $45 \%$ of tobacco residue and fired at $850^{\circ} \mathrm{C}$ and $900^{\circ} \mathrm{C}$. In general, thermal conductivity decreases as the porosity increases. This is the result of the contribution of a higher porosity, which reduces thermal conductivity, especially in cases where pores are closed and not interconnected. The behavior related to the increase of porosity with a decrease in thermal conductivity is related to the release of gas from the burning of organic material, generating spacings with thermal conductivity close to the air $\left(0.023 \mathrm{~W} \cdot \mathrm{m}^{-1} \cdot \mathrm{K}^{-1}\right)$. As sintering temperature increases from $850{ }^{\circ} \mathrm{C}$ to $900{ }^{\circ} \mathrm{C}$, thermal conductivity decreases. In this case, although the porosities are relatively similar, there may be a greater contribution of the larger pores in the glass foams obtained at $900{ }^{\circ} \mathrm{C}$, as observed in Figure 3 . The lower value of thermal conductivity obtained in this work is similar to the result of glass foams produced using organic waste as a foaming agent (ranging from 0.06 to $\left.0.15 \mathrm{~W} \cdot \mathrm{m}^{-1} \cdot \mathrm{K}^{-1}\right){ }^{6}$. Thermal conductivity values of glass foams obtained with organic porous agent were lower than traditional types of glass $\left(1.00 \mathrm{~W} \cdot \mathrm{m}^{-1} \cdot \mathrm{K}^{-1}\right)^{29}$ and ranged from 0.72 to $0.087 \mathrm{~W} \cdot \mathrm{m}^{-1} . \mathrm{K}^{-1}$. These glass foams have similar characteristics to materials such as bricks and ceramic tiles (varying between 1.05 and $0.70 \mathrm{~W} \cdot \mathrm{m}^{-1} \cdot \mathrm{K}^{-1}$, according to their density), concrete with expanded clay (1.05 and $0.17 \mathrm{~W} \cdot \mathrm{m}^{-1} \cdot \mathrm{K}^{-1}$ ) and fiber-cement (ranging from 0.95 to $\left.0.65 \mathrm{~W} \cdot \mathrm{m}^{-1} \cdot \mathrm{K}^{-1}\right)^{29}$. Glass foams produced from transparent

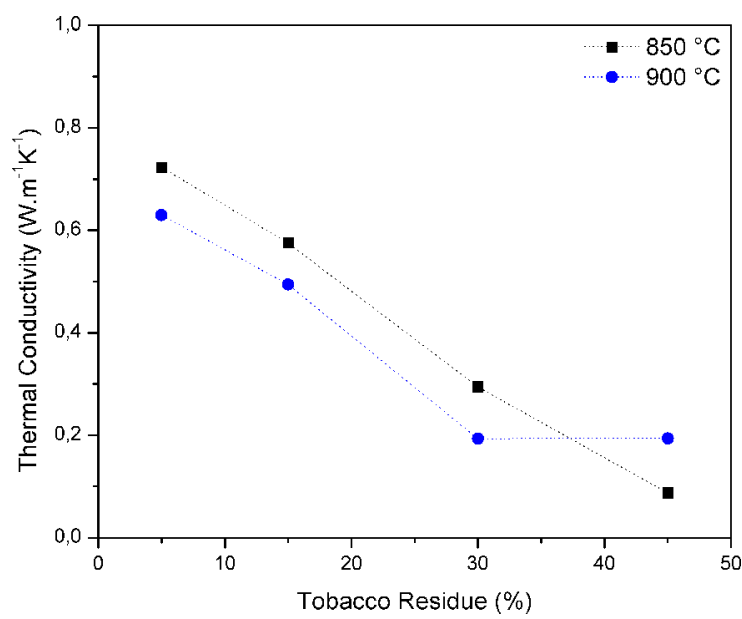

Figure 5. Thermal conductivity for glass foams produced after addition of $5,15,30$ and $45 \%$ (mass) of $\mathrm{T}$ and fired at $850^{\circ} \mathrm{C}$ and $900{ }^{\circ} \mathrm{C}$. 
glass bottles and dolomite presented thermal conductivity varying between 0.29 and $0.55 \mathrm{~W} \cdot \mathrm{m}^{-1} \cdot \mathrm{K}^{-1} 30$.

Figure 6 shows mechanical strength results obtained for the different formulations. It is possible to observe that mechanical resistance is strongly influenced by porosity, that is, the larger the porosity, the lower the mechanical resistance ${ }^{6}$. The glass foam with the highest porosity $(30 \%$ tobacco residue fired at $900^{\circ} \mathrm{C}$ ) has the lowest compressive strength (approximately $2.8 \mathrm{MPa}$ ). In addition, glass foam fired at $850{ }^{\circ} \mathrm{C}$, containing $45 \% \mathrm{~T}$, which presented better thermal insulation characteristics, had a compressive strength of 2.1 MPa and the lowest resistance between the obtained foams. This is in agreement with values found in the literature ${ }^{31-32}$.

It is worth noting that, in the glass foams obtained with $30 \%$ tobacco residue fired at $850{ }^{\circ} \mathrm{C}$ all have properties within the range of commercial foaming properties. That is, porosity above $60 \%$, thermal conductivity of 0.08 and mechanical strength of approximately $2.8 \mathrm{MPa}$. The magnitude of the measured properties of the glass foams produced is adequate for a number of applications requiring low thermal conductivity.

\section{Conclusions}

Discarded glass bottles were converted into glass foams using tobacco residue ( $5-45 \%$ by mass) as a porogenic agent. Glass foams produced after sintering at 850 and $900{ }^{\circ} \mathrm{C}$ have porosities between $36.7 \%$ - 83.5\%, mechanical strength between $34 \mathrm{MPa}$ and $2.1 \mathrm{MPa}$ and thermal conductivity between 0.72 and $0.087 \mathrm{~W} \cdot \mathrm{m}^{-1} \mathrm{~K}^{-1}$. For the use as thermal insulation, glass foam containing $30 \%$ organic residue and fired at $850{ }^{\circ} \mathrm{C}$ proved to be more efficient due to its low thermal conductivity $\left(0.08 \mathrm{~W} \cdot \mathrm{m}^{-1} \mathrm{~K}^{-1}\right)$, maintaining its main physical and mechanical characteristics with a compression ratio of 2.1 $\mathrm{MPa}$. This glass foam synthesis process is relatively simple and does not require the use of

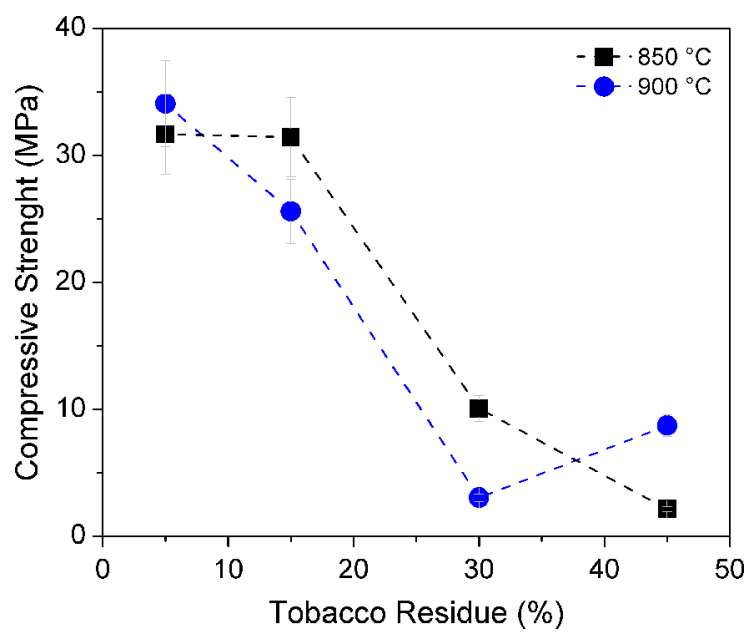

Figure 6. Compressive strength of glass foams produced as function of $\mathrm{T}$ content and fired temperature. any toxic additives. This combination provides advantageous properties for applications in sustainable constructions and energy efficiency. They contribute greatly to the sustainable life cycle of these materials and give additional value to tobacco residue.

\section{Acknowledgments}

Authors would like to thanks funding agencies CAPES and CNPq (Process n ${ }^{\circ}$ 427402/2016-6) for financial support.

\section{References}

1. CEMPRE - Compromisso Empresarial para Reciclagem. Vidro. Available from: $<$ http://cempre.org.br/artigo-publicacao/fichatecnica/id/6/vidro $>$. Access in: 05/05/2018.

2. Bernardo E, Cedro R, Florean M, Hreglich S. Reutilization and stabilization of wastes by the production of glass foams. Ceramics International. 2007;33(6):963-968.

3. Scheffler M, Colombo P, eds. Cellular Ceramics: Structure, Manufacturing, Properties and Applications. Hoboken: John Wiley \& Sons; 2006.

4. de Sousa E, Rambo CR, Ortega FS, de Oliveira APN, Pandolfelli VC. Espumas vítreas do sistema $\mathrm{Li}_{2} \mathrm{O}-\mathrm{ZrO}_{2}-\mathrm{SiO}_{2}-\mathrm{Al}_{2} \mathrm{O}_{3}$ produzidas pelo processo gelcasting. Cerâmica. 2009;55(334):157-162.

5. Ji R, Zhang Z, He Y, Liu L, Wang X. Synthesis, characterization and modeling of new building insulation material using ceramic polishing waste residue. Construction and Building Materials. 2015;85:119-126.

6. Arcaro S, Maia BGO, Souza MT, Cesconeto FR, Granados L, Oliveira APN. Thermal Insulating Foams Produced from Glass Waste and Banana Leaves. Materials Research. 2016;19(5):10641069.

7. Silva LL, Ribeiro LCN, Santacruz G, Arcaro S, Alves AK, Bergmann CP. Glass Foams Produced from Glass and Yerba Mate (Ilex paraguarinensis) Waste. FME Transactions. 2018;46(1):70-79.

8. Onorevoli B, Maciel GPS, Machado ME, Corbelini V, Caramão EB, Jacques RA. Characterization of feedstock and biochar from energetic tobacco seed waste pyrolysis and potential application of biochar as an adsorbent. Journal of Environmental Chemical Engineering. 2018;6(1):1279-1287.

9. Onorevoli B, Machado ME, Polidoro AS, Corbelini VA, Carama o EB, Jacques RA. Pyrolysis of Residual Tobacco Seeds: Characterization of Nitrogen Compounds in Bio-oil Using Comprehensive Two-Dimensional Gas Chromatography with Mass Spectrometry Detection. Energy \& Fuels. 2017;31(9):94029407.

10. Sunchem. Solaris application. Available from: $<\mathrm{http}: / / \mathrm{www}$. sunchem.nl/markets/\#biofuel $>$. Access in: 01/05/2018.

11. Wegner D, Santos MS, Padula AD. O papel da produção de biocombustíveis para o desenvolvimento local: uma análise no arranjo fumageiro gaúcho. Gestão Contemporânea (FAPA). 2010;7:7-32. 
12. BiodieselBR. Tabaco energético em estudo para produção de biocombustiveis; 2016. Available from: $<\mathrm{https://www.biodieselbr.}$ com/noticias/materia-prima/outras/tabaco-energetico-estudoproducao-biocombustiveis-260116.htm >. Access in: 05/05/2018.

13. ASTM International. ASTM E871-82 - Standard Test Method for Moisture Analysis of Particulate Wood Fuels. West Conshohocken: ASTM International; 2013.

14. ASTM International. ASTM E872-82 - Standard Test Method for Volatile Matter in the Analysis of Particulate Wood Fuels. West Conshohocken: ASTM International; 2006.

15. ASTM International. ASTM E1755-01 - Standard Test Method for Ash in Biomass. West Conshohocken: ASTM International; 2015.

16. ASTM International. ASTM E1756-08 - Standard Test Method for Determination of Total Solids in Biomass. West Conshohocken: ASTM International; 2015.

17. ASTM International. ASTM E112-12 - Standard Test Methods for Determining Average Grain Size. West Conshohocken: ASTM International; 2012.

18. ASTM International. ASTM D3576-15 - Standard Test Method for Cell Size of Rigid Cellular Plastics. West Conshohocken: ASTM International; 2015.

19. ASTM International. ASTM C133-97-Standard Test Methods for Cold Crushing Strength and Modulus of Rupture of Refractories. West Conshohocken: ASTM International; 2015.

20. Fernández Navarro JM. El vidrio. Madrid: Consejo Superior de Investigaciones Cientificas; 2003, 593 p.

21. Souza MT, Maia BGO, Teixeira LB, de Oliveira KG, Teixeira AHB, de Oliveira APN. Glass foams produced from glass bottles and eggshell wastes. Process Safety and Environmental Protection. 2017;111:60-64.

22. Petersen RR, König J, Yue Y. The viscosity window of the silicate glass foam production. Journal of Non-Crystalline Solids. 2017;456:49-54.
23. Teixeira LB, Fernandes VK, Maia BGO, Arcaro S, de Oliveira APN. Vitrocrystalline foams produced from glass and oyster shell wastes. Ceramics International. 2017;43(9):6730-6737.

24. Pokorny A, Vicenzi J, Bergmann CP. Influência da adição de alumina na microestrutura da espuma vítrea. Cerâmica. 2008;54(329):97-102.

25. D'Amore GKO, Caniato M, Travan A, Turco G, Marsich L, Ferluga A, et al. Innovative thermal and acoustic insulation foam from recycled waste glass powder. Journal of Cleaner Production. 2017;165:1306-1315.

26. Cesconeto FR, Arcaro S, Maia BGO, Souza MT, Rodrigues Neto JB, Oliveira APN. Materiais celulares vítreos obtidos via colagem de gel de uma emulsão de óleo vegetal. Matéria (Rio de Janeiro). 2016;21(2):385-390.

27. Deubener J, Brückner R, Hessenkemper H. Nucleation and crystallization kinetics on float glass surfaces. Glastechnische Berichte. 1992;65(9):256-266.

28. Zanotto ED. Surface crystallization kinetics in soda-limesilica glasses. Journal of Non-Crystalline Solids. 1991;129(13):183-190

29. Associação Brasileira de Normas Técnicas (ABNT). NBR 15220-1 - Desempenho Térmico de Edificações-Parte 1: Definições, símbolos e unidades. Rio de Janeiro: ABNT; 2003.

30. Pokorny A, Vicenzi J, Pérez Bergmann C. Influence of heating rate on the microstructure of glass foams. Waste Management \& Research. 2011;29(2):172-179.

31. Teixeira LB, Maia BGO, Arcaro S, Sellin N, Oliveira APN. Production and characterization of vitrocrystalline foams from solid wastes. Matéria (Rio de Janeiro). 2017;22(4):e11884.

32. Wu JP, Boccaccini AR, Lee PD, Kershaw MJ, Rawlings RD. Glass ceramic foams from coal ash and waste glass: production and characterisation. Advances in Applied Ceramics. 2006;105(1):32-39. 